\title{
The Effect of Steamed Tempeh on Hemoglobin Levels and Body Weight in Pregnant Women at the Kalar - Kalar Health Center, Aru Islands District
}

\author{
Ira Febriyanti ${ }^{1}$, Saifuddin Sirajuddin'², Hasnawati Amqam ${ }^{3}$ \\ ${ }^{1}$ Public Health Graduate School, Hasanuddin University, Makassar, Indonesia \\ ${ }^{2}$ Department of Nutrition, Faculty of Public Health, Hasanuddin University, Makassar, Indonesia \\ ${ }^{3}$ Department of Environmental Health, Faculty of Public Health, Hasanuddin University, Makassar, Indonesia \\ Corresponding Author: Ira Febriyanti
}

\begin{abstract}
Background: Nutrition of pregnant women is very influential on fetal growth, one of which is iron deficiency anemia. Iron deficiency increases in pregnant women with increasing age in pregnancy. Significantly low intake of nutrients will make pregnant women experience Chronic Energy Deficiency. The nutritional content of tempeh can be used to meet the nutritional needs of pregnant women.
\end{abstract}

Objective: The aim of this study was to analyze the effect of giving steamed tempeh to the increase in hemoglobin and Body Weight levels in pregnant women at the Kalar-kalar Health Center, Aru Islands Regency.

Method: This type of research is a quasiexperimental with a pre-posttest control group design. The intervention was given to the respondents as many as 24 people with 12 people in the control group and 12 people in the treatment group. Sampling purposive sampling. Subjects were taken from two villages in the working area of the Kalar-Kalar Public Health Center which have relatively the same geography and socioeconomic status and only pregnant women with $\mathrm{Hb}<11 \mathrm{G} / \mathrm{dL}$ were selected. The form of treatment was giving 100 $\mathrm{G}$ of steamed tempeh 2 times a week for 30 days while the control group was given biscuits for pregnant women 2 times per week 100 G. Data analysis used univariate and bivariate analysis with paired T test and Mann Whitney.

Results: Mann Whitney test results of the effect of steamed tempeh on weight gain in the treatment group obtained a p-value of 0.050 $(p=0.05)$. Differences in hemoglobin levels in anemic pregnant women with a p-value of 0.018
$(<0.05)$ with a mean difference of $0.42 \mathrm{G} / \mathrm{dL}$ in the pre-posttest treatment group and the control group with a p-value of $0.217(<0.05)$ with a mean difference of $0.21 \mathrm{G} / \mathrm{d} \mathrm{dL}$.

Conclusion: There is an effect of giving steamed tempeh to increase hemoglobin and body weight in pregnant women.

Keywords: Anemia, Pregnant women, Hemoglobin, Body Weight, Tempeh.

\section{INTRODUCTION}

Anemia in pregnancy is a national problem reflecting the value of the socioeconomic welfare of the community, influencing broader the quality of human resources. About $35-75 \%$ of pregnant women experience iron deficiency, and the risk increase along with gestational age (1). According to WHO, it was estimated that $40 \%$ of pregnant women (95\% CI: 36.4 to $44.7 \%$ ) were anemic globally in 2016, with the highest regional prevalence in Southeast Asia (58.2\%) and the lowest in America (25.5\%) (2). Pregnant women with iron deficiency have been $42.6 \%$ overall and $38.8 \%$ in the second trimester (3). This condition causes a constant high perinatal mortality rate and maternal mortality and morbidity (4).

The nutritional intake of pregnant women from underprivileged communities decreased significantly and made them experience Chronic Energy Deficiency. The government's program to reduce anemia in pregnant women is by distributing $\mathrm{Fe}$ 
supplement tablets for free. Besides, creating various efforts to reduce the incidence of anemia in pregnant women by increasing the coverage of giving iron tablets to pregnant women. Maternal nutritional status is influenced by consuming nutritious foods and high iron content such as green leafy vegetables, red meat, cereals, eggs, and nuts in mothers to prevent nutritional anemia in pregnant women.

Tempeh is made with soybeans contains macronutrients (carbohydrates, protein, fat, potassium, calcium, and phosphorus) and micronutrients (Iron, Zinc, Sodium, and Water). One of the local foods rich in nutrients and widely available, and relatively cheap and easy to obtain is tempeh. The previous study found that the total protein content in a mixture of fermented soybean tempeh (Glycine max $L$ ) $>48$ hours and pineapple (Ananas comosus) stem extract was $31.90 \%$ for comparison of $1: 1$ ratio, $36.51 \%$ for $1: 2$ ratio, and $29.46 \%$ for 1:3 ratio. Another study showed an effect of tempeh milk on the average $\mathrm{Hb}$ level with $\mathrm{p}$-value $=0.005$ with a mean difference of 0.91 ; there is the effect of protein, and $\mathrm{Fe}$ tablets intake on $\mathrm{Hb}$ levels (5).

Research on giving steamed tempeh to increase hemoglobin levels in anemic pregnant women is still rarely found. Based on this, this study aims to assess the effect of giving steamed tempeh to increase hemoglobin levels and body weight in pregnant women.

\section{METHODS}

This research used a Quasy Experiment with a non-randomized pretestposttest control group design. The sample involved were 40 pregnant women in the working area of the Siwalima Health Center by purposive sampling, divided into intervention group and control group. The intervention group was obtained $100 \mathrm{~g}$ steamed tempeh twice a week for 30 days and controlled the $\mathrm{Fe}$ tablets intake and tannins. Meanwhile, the control group was obtained special biscuits intended for pregnancy.

The inclusion criteria of the research sample included 1) Pregnant women with gestational age in the second and third trimesters; 2) Age of pregnant women 15-40 y.o; 3) Hemoglobin level $<11$ g/dl (visually indicated suffering from anemia); 4) Pregnant women with upper arm circumference $<23.5 \mathrm{~cm}$; 5) willing to participate in the research process. Exclusion Criteria included 1) Refused to participate; 2) Pregnant women with infectious diseases (pulmonary TB and indications for COVID-19). Drop Out criteria were resigning or experiencing illness during the intervention implementation period.

The data collection was that preliminary measurements (pretest) were carried out before the intervention, including body weight, $\mathrm{Hb}$ levels, nutritional intake, and family socioeconomics. The duration of the intervention was carried out for 30 days, and measurement (posttest) was conducted on the day $31^{\text {st }}$. Data processing was done computerized using the SPSS 21 for windows program through Paired t-Test and Independent T-Test.

The research was carried out after obtaining ethical approval recommendations from the Faculty of Public Health, Hasanuddin University: 6262/UN4.14.1/TP.01.02/2021 in 2021.

\section{RESULTS}

\section{Characteristics of Respondents}

Table 1 Characteristics of Respondents

\begin{tabular}{|c|c|c|c|}
\hline \multirow[t]{3}{*}{ Characteristics } & \multicolumn{2}{|l|}{ Group } & \multirow{3}{*}{ Total } \\
\hline & Intervention & Control & \\
\hline & $(n=12)$ & $(n=12)$ & \\
\hline \multicolumn{4}{|l|}{ Age (Years) } \\
\hline $17-20$ & $2(8 \%)$ & $2(8 \%)$ & $4(17 \%)$ \\
\hline $21-30$ & $7(29 \%)$ & $8(33 \%)$ & $15(63 \%)$ \\
\hline$\geq 31$ & $3(13 \%)$ & $2(8 \%)$ & $5(21 \%)$ \\
\hline \multicolumn{4}{|l|}{ Parturition } \\
\hline 0 & $3(13 \%)$ & 0 & $3(13 \%)$ \\
\hline 1 & $2(8 \%)$ & $5(21 \%)$ & $7(29 \%)$ \\
\hline 2 & 0 & $1(4 \%)$ & $1(4 \%)$ \\
\hline 3 & $2(8 \%)$ & $3(13 \%)$ & $5(21 \%)$ \\
\hline$>4$ & $5(21 \%)$ & $3(13 \%)$ & $8(33 \%)$ \\
\hline
\end{tabular}


Ira Febriyanti et.al. The Effect of Steamed Tempeh on Hemoglobin Levels and Body Weight in Pregnant Women at the Kalar - Kalar Health Center, Aru Islands District

Table 1 shows that the age of the intervention group and the control group was relatively homogeneous; the largest was at the age of 17-20 years in intervention and control groups, of 2 respondents (8\%) of each. Age 20-30 years were 7 respondents (29\%) in the intervention group and 8 respondents (33\%) in the control group. Most of the respondents in 5-6 months old pregnancy were 4 respondents (17\%) for the intervention group and 7 respondents (29\%) in the control group. Respondents mostly have never given birth in the control group than in the intervention group of 3 respondents (13\%).

Table 2 Distribution of respondents based on Antenatal care services

\begin{tabular}{|c|c|c|c|}
\hline \multirow[t]{2}{*}{ Variable } & \multicolumn{2}{|l|}{ Group } & \multirow[t]{2}{*}{ Total } \\
\hline & $\begin{array}{l}\text { Intervention }(\mathrm{n}= \\
\text { 12) }\end{array}$ & $\begin{array}{l}\text { Control }(\mathrm{n}= \\
\text { 12) }\end{array}$ & \\
\hline \multicolumn{4}{|c|}{ Pregnancy test } \\
\hline No & $0(0.0 \%)$ & $0(0.0 \%)$ & $0(0.0 \%)$ \\
\hline Yes & $12(50 \%)$ & $12(50 \%)$ & $\begin{array}{l}24 \\
(100 \%)\end{array}$ \\
\hline \multicolumn{4}{|c|}{ Gestational age before intervention } \\
\hline Trimester I & $2(8 \%)$ & $5(21 \%)$ & $7(29 \%)$ \\
\hline Trimester II & $4(17 \%)$ & $7(29 \%)$ & $11(46 \%)$ \\
\hline $\begin{array}{l}\text { Trimester } \\
\text { III }\end{array}$ & $6(25 \%)$ & 0 & \\
\hline \multicolumn{4}{|c|}{ Immunization Service } \\
\hline No & $6(25 \%)$ & 0 & $6(25 \%)$ \\
\hline Yes & $6(25 \%)$ & $12(50 \%)$ & $18(75 \%)$ \\
\hline \multicolumn{4}{|c|}{ Blood pressure check } \\
\hline No & 0 & 0 & $0(0.0 \%)$ \\
\hline Yes & $12(50 \%)$ & $12(50 \%)$ & $\begin{array}{l}24 \\
(100 \%)\end{array}$ \\
\hline \multicolumn{4}{|c|}{ Additional Fe supplementation } \\
\hline No & $12(50 \%)$ & $12(50 \%)$ & $\begin{array}{l}24 \\
(100 \%)\end{array}$ \\
\hline Yes & 0 & 0 & $0(0.0 \%)$ \\
\hline
\end{tabular}

Table 2 shows that health services for pregnant women at the Kalar-Kalar Health Center were limited. The standard of examination provided was only blood pressure checks for both groups. For health services such as immunization and additional $\mathrm{Fe}$ supplementation in the intervention group, $50 \%$ had never received immunization nor $\mathrm{Fe}$ supplementation during pregnancy.

Hemoglobin Levels and Body weight of Pregnant Women before and after giving steamed tempeh
Table 3 Analysis of Hemoglobin Levels between Treatment and Control Groups Before and After Giving Tempe

\begin{tabular}{|l|l|l|l|}
\hline \multirow{2}{*}{ Hb } & Groups & \multirow{2}{*}{ P vaIue } \\
\cline { 2 - 3 } & $\begin{array}{l}\text { Intervention } \\
\text { (n=12) }\end{array}$ & $\begin{array}{l}\text { ControI } \\
\text { (n=12) }\end{array}$ & \\
\hline $\begin{array}{l}\text { Pre-test } \\
\text { Mean } \pm \text { SD (G/dI) }\end{array}$ & $8,13 \pm 1,33$ & $8,75 \pm 4,51$ & 0,379 \\
\hline $\begin{array}{l}\text { Post-test } \\
\text { Mean } \pm \text { SD (G/dI) }\end{array}$ & $8,55 \pm 1,04$ & $8,96 \pm 4,78$ & 0,040 \\
\hline P vaIue & & 0,217 & \\
\hline$\Delta^{3}$ & 0,018 & $0,21 \pm 0,57$ & 0,395 \\
\hline
\end{tabular}

${ }^{1}$ Paired SampIes T Test; ${ }^{2}$ WiIcoxon Signed Ranks Test; ${ }^{3}$ MannWhitney Test;

$\Delta=$ Change between pre-test and post-test.

Table 3 shows a change in the increase in $\mathrm{Hb}$ levels in the intervention group (8.55 \pm 1.04$)$. While in the control group (8.96 \pm 4.78$)$. with a p-value of 0.018 $(=0.05)$. The $p$-value shows that there is a difference in the increase in $\mathrm{Hb}$ levels before and after the intervention in the intervention group but not in the control group, p-value $0.217(>0.05)$. The value of the change or difference in the mean scores before and after the intervention between groups was slightly larger in the control group but did not show a significant difference $(\mathrm{p}=0.395)$.

Table 4 Analysis of Body Weight between Treatment and Control Groups Before and After Giving Tempe

\begin{tabular}{|l|l|l|l|}
\hline \multirow{2}{*}{ Body Weight } & \multicolumn{2}{|l|}{ Groups } & \multirow{2}{*}{ vaIue $^{\mathbf{3}}$} \\
\cline { 2 - 3 } & $\begin{array}{l}\text { Intervention } \\
\text { (n=12) }\end{array}$ & $\begin{array}{l}\text { ControI } \\
\text { (n=12) }\end{array}$ & \\
\hline $\begin{array}{l}\text { Pre-test } \\
\text { Mean } \pm \text { SD (G/dI) }\end{array}$ & $50,05 \pm 2,93$ & $46,05 \pm 4,55$ & 0,073 \\
\hline $\begin{array}{l}\text { Post-test } \\
\text { Mean } \pm \text { SD (G/dI) }\end{array}$ & $51,17 \pm 3,78$ & $43,88 \pm 13,19$ & 0,053 \\
\hline P vaIue & & 0,473 & \\
\hline$\Delta^{3}$ & 0,050 & $-2,16 \pm 10,10$ & 0,603 \\
\hline
\end{tabular}

${ }^{1}$ Paired Samples T Test; ${ }^{2}$ WiIcoxon Signed Ranks Test; ${ }^{3}$ MannWhitney Test;

$\Delta=$ Change between pre-test and post-test.

Table 4 shows a change in weight gain in the intervention group (51.17 \pm 3.78$)$. While in the control group (43.88 \pm 13.19$)$. with a p-value of $0.050(=0.05)$. The $p$-value indicates that there is a difference in weight gain before and after the intervention in the intervention group but not in the control group, p-value $0.473(>0.05)$. The value of the change or difference in the mean scores before and after the intervention between groups was slightly larger in the control group but did not show a significant difference $(\mathrm{p}=0.603)$. 
Ira Febriyanti et.al. The Effect of Steamed Tempeh on Hemoglobin Levels and Body Weight in Pregnant Women at the Kalar - Kalar Health Center, Aru Islands District

\section{Nutrient Intake}

Table 5 Nutritional Intake After Intervention in Intervention and Control Groups

\begin{tabular}{|c|c|c|c|c|c|c|c|c|c|c|}
\hline \multirow[t]{2}{*}{ Nutrition intake } & \multirow{2}{*}{$\mathbf{N}$} & \multicolumn{4}{|c|}{ Intervention } & \multicolumn{4}{|c|}{ Control } & \multirow[b]{2}{*}{$\mathbf{p}$} \\
\hline & & Mean & SD & Min & Max & Mean & SD & Min & Max & \\
\hline Energy & 12 & 631,5 & 210,33 & 387,4 & 1063,8 & 579,02 & 192,16 & 347,4 & 985,7 & 0.729 \\
\hline Carbohydrate & 12 & 147,1 & 49,11 & 92,9 & 243,7 & 134,08 & 61,11 & 98,2 & 283,2 & 0.419 \\
\hline Protein & 12 & 6,94 & 5,27 & 0,3 & 14 & 5,55 & 5,31 & 1,1 & 15 & 0.525 \\
\hline Fat & 12 & 2,94 & 2,48 & 0,1 & 7,1 & 3,91 & 2,54 & 0,3 & 7,2 & 0.339 \\
\hline $\mathrm{Fe}$ & 12 & 1,31 & 0,72 & 0,5 & 2,7 & 1,46 & 0,77 & 0,4 & 2,9 & 0.664 \\
\hline Vit C & 12 & 6,1 & 7,41 & 0 & 15,2 & 6,16 & 6,47 & 0 & 14 & 0.483 \\
\hline Zink & 12 & 0,42 & 0,21 & 0,1 & 0,9 & 0,36 & 0,24 & 0,1 & 0,8 & 0.502 \\
\hline Total calories & 12 & 796,35 & 262,36 & 481,3 & 1340,4 & 730,58 & 256,22 & 463,2 & 1259,1 & 0.644 \\
\hline
\end{tabular}

Table 5 of the three groups show that the intake of energy, carbohydrates, protein, fat, iron, vitamin $\mathrm{C}$, and zinc was lacking. It was influenced by the geographical condition of the Kalar-Kalar Health Center, which causes the eating habits of the population, including pregnant women in the islands, to eat only once a day. Thus, commonly, they experience a calorie deficit or less caloric intake than their body needs based on their body mass index value. So, the intervention of steamed tempeh for a month was not enough to contribute to the BMI value and hemoglobin levels improvement in pregnant women at the Kalar-Kalar Health Center working area.

\section{DISCUSSION}

\section{Effect of Steamed Tempeh on Hemoglobin Levels}

The latest hemoglobin measurement was carried out on the $31^{\text {st }}$ day after 30 days of intervention of 100 grams of steamed tempeh 2 times a week. From the results of measurements and analysis carried out, it was found that both groups experienced an increase that the average hemoglobin level in the intervention group had increased compared to before. Before the intervention, the hemoglobin level of the intervention group was $8.1 \mathrm{~g} / \mathrm{dl}$, and after the intervention during 30 days of steamed tempeh became $8.5 \mathrm{~g} / \mathrm{dl}$. In the control group who were not given steamed tempeh, there was also an increase from $8.7 \mathrm{~g} / \mathrm{dl}$ to be $8.9 \mathrm{~g} / \mathrm{dl}$ after 30 days.

Providing appropriate nutrition will greatly help improve and prevent anemia conditions (6). Tempeh is a functional food ingredient that can overcome anemia (7). Tempeh contains nutrients, e.g., iron, folic acid, B vitamins which can increase hemoglobin levels. Tempeh is a source of vegetable protein that contains iron in the form of non-heme. The fermentation process in tempeh by enzymes produced by the fungus Rhizopus oligosporus can increase the solubility of iron from $24.3 \%$ in raw soybeans to $40.5 \%$ in tempeh. However, the cooking process will also change the solubility of iron (8). Another study showed that the increase in $\mathrm{Fe}$ and ascorbic acid from tempeh and fruit rich in vitamin $\mathrm{C}$ did not improve the Fe status of pregnant women in rural Indonesia with a relatively good traditional diet (9). However, in a quasi-experimental study with Indonesian pregnant women in the third trimester of pregnancy $(\mathrm{N}=32), 100$ g/day of tempeh milk + iron supplementation for 30 days increased serum hemoglobin levels as well as protein and iron absorption, compared to ironcontaining iron. supplement only (10). Consuming homemade soy milk can significantly increase the average $\mathrm{Hb}$ level of pregnant women, with an average increase in $\mathrm{Hb}$ levels of $2.99 \pm 1.422 \mathrm{mg} / \mathrm{dl}$ (11).

Another factor related to hemoglobin levels is physical activity, any movement from skeletal muscles requiring energy expenditure. Physical activity causes an increase in metabolism so that there are more acids (hydrogen ions and lactic acid), thus lowering the $\mathrm{pH}$, low $\mathrm{pH}$ will reduce the attraction between oxygen and hemoglobin (12). This causes the 
hemoglobin to release more oxygen, thereby increasing oxygen delivery to the muscles. Regular physical activity can increase hemoglobin levels (13), but excessive physical activity can cause hemolysis and reduce the amount of hemoglobin. This theory strengthens the suspicion of excessive physical activity factors in pregnant women at the Kalar-Kalar Health Center still experiencing anemia even though they have consumed steamed tempeh. Regularly, local pregnant women still routinely collect wood in the forest on foot for fuel for their cooking. So, the nutrients consumed are less than the energy used mainly during pregnancy, where mothers have to share nutrients with the fetus. Thus, in the results of this study, there was no improvement from the status of the anemia category to normal despite an increase in hemoglobin levels after the intervention.

\section{Effect of Giving Steamed Tempe on Body Weight}

Body weight is one of the parameters for assessing nutritional status in general which is very sensitive to sudden changes either due to infectious diseases or decreased food consumption. Weight gain per week is $0.35 \mathrm{~kg}$ for pregnant women under normal circumstances. Then in the results of this study which showed the average value of changes in body weight gain in both groups, but the biggest change, namely an average increase of $1.12 \mathrm{~kg}$ occurred in the treatment group, while in the control group the weight before the average was 0.64 with a comparison between the treatment and control groups, the results obtained that the average weight gain in the intervention group was higher (51.17 \pm 2.93 $\mathrm{kg})$ than the control group (43.88 \pm 13.19 $\mathrm{kg}$ ) strengthened by statistical tests indicated by a significant $\mathrm{p}$ value. (0.05).

Other studies have shown that BMI in the first trimester maternal is the most important indicator of maternal weight gain during pregnancy, and BMI is inversely proportional to maternal weight gain during pregnancy except for low BMI (14). There was no significant difference between the intervention group and the control group in increasing the BMI value due to the relatively similar daily consumption patterns, economic factors, knowledge, and daily physical activity. Besides, the intervention group was only received additional food in the form of 100 grams of steamed tempeh per person only 2 times a week. Theoretically, it will increase nutritional value under normal activity conditions for pregnant women. However, under conditions of limited foodstuffs and higher physical activity, the intervention of 100-gram steamed tempeh twice a week would not effectively improve the nutritional status of pregnant women. The results of this study are relevant to Aini (2020); the difference in nutritional status changes before and after consuming brownies made from tempeh was $-0.40 \mathrm{SD}$, while the difference in the control group was -0.24 elementary school. This is due to the minimal improvement in average body weight in the control group, so that it has less effect on improving the nutritional status of malnourished children (15).

\section{CONCLUSION}

The intervention of tempeh on hemoglobin levels in pregnant women at the Kalar-Kalar Health Center working area did not change their status from anemia to normal. Besides, no significant difference in hemoglobin levels between the intervention group and the control group. Moreover, there was a significant effect of tempeh on body weight values in pregnant women at the Kalar-Kalar Health Center, but no significant difference in body weight values between both groups.

\section{Acknowledgement: None}

Conflict of Interest: None

Source of Funding: None

Ethical Approval: Approved 


\section{REFERENCES}

1. Mirzaie F, Eftekhari N, Goldozeian S, Mahdavinia J. Prevalence of anemia risk factors in pregnant women in Kerman, Iran. International Journal of Reproductive BioMedicine. 2010 Jul 10;8(2):66-9.

2. Ohuma EO, Young MF, Martorell R, Ismail LC, Peña-Rosas JP, Purwar M, et al. International values for haemoglobin distributions in healthy pregnant women. EClinicalMedicine. 2020 Dec 2;2930:100660.

3. Zhang Y, Huang X, Chen Z, Yang Q, Li X, Zhang R, et al. Iron Deficiency, a Risk Factor for Thyroid Autoimmunity During Second Trimester of Pregnancy in China. Endocrine Practice. 2020 Jun;26(6):595603.

4. Sholichah N, Lestari NP. Asuhan Kebidanan Komprehensif Pada Ny. Y (Hamil, Bersalin, Nifas, BBL, Dan KB. Jurnal Komunikasi Kesehatan (Edisi 14). 2017;8(01):79-95.

5. Yuniwati. Pengaruh Pemberian Susu Tempe Terhadap Kadar Haemoglobin Pada Ibu Hamil Trimester III. Jurnal Media Kesehatan. 2014;7(2):169-76.

6. Prentice AM, Mendoza YA, Pereira D, Cerami C, Wegmuller R, Constable A, et al. Dietary strategies for improving iron status: balancing safety and efficacy. Nutr Rev. 2017 Jan;75(1):49-60.

7. Ariani D, Angwar M. Produk pangan berbasis tempe dan aplikasinya. Cetakan pertama. Menteng, Jakarta: LIPI Press; 2018. 65 p.

8. Pinasti L, Nugraheni Z, Wiboworini B. Potential of tempeh as a functional food in increasing hemoglobin levels inadolescent anaemia. Jurnal AcTion: Aceh Nutrition Journal. 2020;5(1):19-26.

9. Wijaya-Erhardt M, Muslimatun S, Erhardt JG. Fermented soyabean and vitamin C-rich fruit: a possibility to circumvent the further decrease of iron status among iron-deficient pregnant women in Indonesia. Public Health Nutrition. 2011 Dec;14(12):2185-96.

10. Novianti, Asmariyah, Suriyati. Pengaruh Pemberian Susu Tempe Terhadap Kadar Haemoglobin Pada Ibu Hamil Tm III Di Kota Bengkulu. Journal Of Midwifery. 2019 May 17;7(1):23-9.

11. Farisni TN, Fitriani F, Yarmaliza Y. The Effectiveness of Homemade Soymilk in Increasing Haemoglobin $(\mathrm{Hb})$ Levels in Pregnant Women. J-Kesmas: Jurnal Fakultas Kesehatan Masyarakat (The Indonesian Journal of Public Health). 2019 Oct 23;6(2):41-8.

12. Kosasi L, Oenzil F, Yanis A. Hubungan Aktivitas Fisik terhadap Kadar Hemoglobin padaMahasiswa Anggota UKM Pandekar Universitas Andalas. Jurnal Kesehatan Andalas. 2014;3(2):178-81.

13. Guyton. Buku Ajar Fisiologi Kedokteran. Jakarta: Penerbit Buku Kedokteran EGC; 2012.

14. Zuhairini Y, Kasmanto H, Nugraha GI. Indeks Massa Tubuh Awal Kehamilan Ibu sebagai Indikator yang Paling Berperan terhadap Kenaikan Berat Badan Ibu Selama Hamil. Majalah Kedokteran Bandung. 2016 Sep 30;48(3):171-5.

15. Aini H. Pengaruh Pemberian Brownis Tempe Subtitusi Wortel (Daucus carota L.) terhadap Status Gizi Siswa Gizi Kurang di SD Kelurahan Samata Kabupaten Gowa. [Makassar]: Universitas Islam Negeri Alauddin; 2019.

How to cite this article: Febriyanti I, Sirajuddin $\mathrm{S}$, Amqam $\mathrm{H}$. The effect of steamed tempeh on hemoglobin levels and body weight in pregnant women at the Kalar - Kalar Health Center, Aru Islands District. Gal Int J Health Sci Res. 2021; 6(4): 10-15. DOI: https://doi.org/10.52403/ gijhsr.20211003 